\title{
The adiposity rebound in the 21st century child- ren: meaning for what?
}

\author{
Min Jae Kang, MD, PhD \\ Department of Pediatrics, Hallym University Sacred Heart Hospital, Hallym University College of Medicine, Anyang, Korea
}

With the increase in the prevalence of overweight and obesity worldwide, early adiposity rebound, which is known to have a strong association with obesity, has recently been a focus of research. Early adiposity rebound is conventionally known to have a close relationship with non-communicable diseases. However, novel insights into early adiposity rebound have implied an acceleration of growth and puberty, which is directly reflected in the trends in the timing of adiposity rebound, in the 21st century compared with in the past. Furthermore, the observation that lean mass changes rather than fat mass changes show a more similar pattern to body mass index trajectories is interesting. In this article, the later outcomes and risk factors of early adiposity rebound are briefly summarized, and the current trends in the timing of adiposity rebound and novel insights into its relationship with body composition are reviewed.

Key words: Body mass index, Adiposity rebound, Obesity

\section{Introduction}

During the developmental period, body mass index (BMI), which is used as an index of obesity, shows an interesting growth trajectory. In general, BMI rapidly increases during the first year of life, then subsequently decreases and reaches a nadir at around 6 years of age. Thereafter, BMI increases again throughout childhood, and this second rise is referred to as the adiposity rebound. Adiposity rebound was first reported in 1984 by Rolland-Cachera et al. ${ }^{1)}$ They found a relationship between the age at adiposity rebound and final adiposity (at age 16 years), and showed that an early rebound (before age 5.5 years) is followed by a higher adiposity level than a later rebound (after age 7 years). ${ }^{1)}$ Since then, numerous studies have suggested early adiposity rebound as a predictive marker of obesity in later childhood, adolescence, and adulthood. ${ }^{2-9)}$

In 2010, approximately 6.7\% of preschool-aged children worldwide were overweight or obese, and this prevalence is predicted to increase to $9.1 \%$ by $2020 .{ }^{10)}$ According to the Korean National Health and Nutrition Examination Survey VII performed in 2016, 8.6\% and 9.6\% of children and adolescents aged 2-18 years were overweight and obese, respectively. ${ }^{11}$ In line with these findings, the timing of adiposity rebound is expected to be different in the 21st century compared with that in the past. In this article, the trends and novel insights in the timing of adiposity rebound with conventional concepts are reviewed.

\section{Determination of adiposity rebound}

The exact timing of adiposity rebound is difficult to judge. The most traditional and best method is to trace an individual's adiposity plot through visual inspection. ${ }^{1,12)}$ However, most
Corresponding author: Min Jae Kang, MD, PhD Department of Pediatrics, Hallym University Sacred Heart Hospital, 22, Gwanpyeong-ro 170beon-gil, Dongan-gu, Anyang 14068, Korea Tel: +82-31-380-3730

Fax: +82-31-380-1900

E-mail: mjkang@hallym.or.kr https://orcid.org/0000-0003-3080-0941

Received: 6 November, 2018

Revised: 4 December, 2018

Accepted: 6 December, 2018
Copyright (c) 2018 by The Korean Pediatric Society

This is an open-access article distributed under the terms of the Creative Commons Attribution NonCommercial License (http://creativecommons.org/ licenses/by-nc/4.0/) which permits unrestricted noncommercial use, distribution, and reproduction in any medium, provided the original work is properly cited. 
previous studies were population studies or cross-sectional surveys, and only a few of them measured data with sufficient frequency to allow identifying the age of adiposity rebound. Moreover, owing to the small body size of children, even minimal errors in weight or height measurement may considerably influence the determination of BMI. To compensate for these practical weaknesses, various statistical approaches have been proposed. ${ }^{5,6,8,12,13)}$

In addition, depending on the characteristics of subjects, followup durations, and measurement intervals, some studies defined the timing of adiposity rebound as the age at which the lowest BMI occurred before the second BMI rise ${ }^{5)}$ or at which a specific BMI increase occurred during the period of adiposity rebound. ${ }^{14,15)}$ Apart from BMI, another study considered the timing of adiposity rebound based on weight and height separately, which implies the velocity rather than the nadir of BMI. ${ }^{16)}$

\section{Later outcomes in children with early adiposity rebound}

\section{Childhood and adult obesity}

Although there are many confounding factors, the close relationship between the timing of adiposity rebound and later obesity is well known. ${ }^{16)}$ The critical and sensitive periods in childhood for the development of obesity were reported to be gestation and early infancy, the period of adiposity rebound, and adolescence. ${ }^{17)}$ During the period of adiposity rebound, high BMI (overweight and obesity) at age 5 years ${ }^{7,16,18-20)}$ or 7 years of age $e^{9)}$ has been proposed to have a significant relationship with adult obesity. Some studies concluded that the timing of adiposity rebound could account for about 30\% of adult obesity that begins in childhood. ${ }^{8,12,21)}$

\section{Non-communicable diseases}

There have been studies on the relationships between early adiposity rebound and non-communicable diseases such as insulin resistance/type 2 diabetes mellitus ${ }^{22-24)}$ and cardiovascular disease, ${ }^{5,24)}$ not only in adulthood but also in adolescence or even earlier. Mo-Suwan et al. ${ }^{23)}$ showed a significant correlation between early adiposity rebound at 3-6 years of age and homeostasis model assessment of insulin resistance values at 8.5 years of age. Koyama et al. ${ }^{5)}$ found that early adiposity rebound is associated with higher triglyceride levels, atherogenic index, apolipoprotein B, and blood pressure, and lower high-density lipoprotein cholesterol levels at 12 years of age.

\section{Risk factors for adiposity rebound}

Many risk factors related to early adiposity rebound have been studied; however, for some of them, the evidence is not yet conclusive.

\section{Parental obesity}

Maternal obesity and paternal obesity were both identified as factors that accelerate the BMI growth trajectory of a child ${ }^{15,16)}$; however, maternal weight seems to be the strongest and most consistent factor related to early adiposity rebound in many previous studies. ${ }^{25-28)}$ According to data from the Generation 1 study in Australia, maternal obesity in early pregnancy showed an odds ratio of 3.7 for early adiposity rebound compared with average adiposity rebound. ${ }^{26)}$ Toschke et al. ${ }^{27)}$ found that maternal BMI was associated with both a positive shifting and skewing in the BMI distribution. Genetic predisposition and sharing environment and habits may influence the adiposity of the child.

\section{Small for gestational age at birth}

A small size at birth per se is well known to be associated with early adiposity rebound, obesity, and metabolic syndrome, ${ }^{29,30)}$ especially in children with early catch-up growth. ${ }^{31)}$ Maeyama et al. ${ }^{14)}$ reported an early age for adiposity rebound often before age 3 years. However, catch-up growth depends not only on birth weight but also on gestational age. The rate of catch-up growth, timing of adiposity rebound, and BMI trajectory during the first 3 years were reported to be dependent on gestational age at birth, which occurred at a boundary of 37 weeks gestational age. ${ }^{14)}$

\section{Breastfeeding}

To date, breastfeeding is the only factor known to have a protective effect against childhood obesity and early adiposity rebound. The mechanism of this protective effect was assumed to involve reducing the plasma insulin level, thereby decreasing fat storage and preventing the development of excessive early adiposity. ${ }^{32)}$ In other words, breastfeeding protects children from insulin resistance. ${ }^{23,33,34)}$ A meta-analysis of studies on long-term health outcomes found that breastfeeding was associated with a lower risk of type 2 diabetes, with an odds ratio of $0.65 .^{35)}$

\section{Other concerns}

Maternal smoking during the pregnancy, ${ }^{15,16)}$ socio-economic status of the family, ${ }^{16)}$ screen time, ${ }^{36)}$ and early protein intake ${ }^{37,38)}$ have been suggested to be related to the timing of adiposity rebound; however, there are discrepancies in findings. Higher protein intake may stimulate the secretion of insulin and insulin-like growth factor-1, both of which accelerate growth and increase the fat mass (FM). ${ }^{39)}$ 


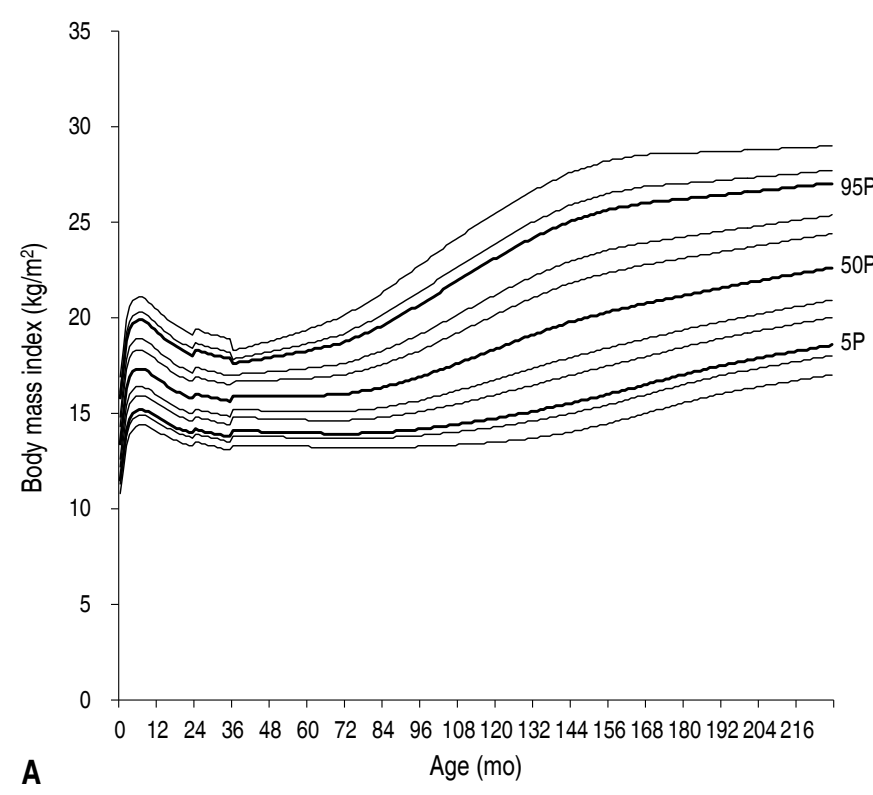

Fig. 1. Body mass index trajectories from birth to 18 years in Korean boys (A) and girls (B). The 1st, 3rd, 5th, 15th, 25th, 50th, 75th, 85th, 95th, 97th, and 99th percentile curves are shown in consecutive order. P, percentile.

\section{Adiposity rebound in 21st century children}

\section{Adiposity curve in Korean children based on the national re- ference}

A BMI curve was plotted using data from the 2017 Korean National Growth Chart (Fig. 1). ${ }^{40)}$ As the 2017 Korean Growth Standard adopted the World Health Organization Child Growth Standards for children aged 0-35 months, there is a transition point at 36 months of age. At 24 months of age, there is another transition point from length-based BMI to height-based BMI. The timing of adiposity rebound was determined when all consecutive BMI values (interval of 1 month) showed an increase after the nadir exceeding $0.1 \mathrm{~kg} /$ $\mathrm{m}^{2}{ }^{411}$

In boys, BMI showed an infantile peak around 6-7 months of age regardless of the BMI percentile. Then, BMI decreased to the nadir value. In the 5th percentile of the BMI curve, the minimum BMI was $13.9 \mathrm{~kg} / \mathrm{m}^{2}$ and adiposity rebound occurred at age 77 months (6.5 years). In the 50th percentile of the BMI curve, the minimum BMI was $15.9 \mathrm{~kg} / \mathrm{m}^{2}$ and adiposity rebound occurred at age 66 months (5.5 years). In the 95th percentile of the BMI curve, the minimum BMI was $17.6 \mathrm{~kg} / \mathrm{m}^{2}$ and adiposity rebound occurred at age of 38 months (3.2 years).

In girls, BMI showed an infantile peak around 6-7 months of age regardless of the BMI percentile. Then, BMI decreased to the nadir value. In the 5 th percentile of the BMI curve, the minimum BMI was $13.7 \mathrm{~kg} / \mathrm{m}^{2}$ and adiposity rebound occurred at age 89 months (7.4 years). In the 50th percentile of the BMI curve, the minimum BMI was $15.7 \mathrm{~kg} / \mathrm{m}^{2}$ and adiposity rebound occurred at age 66 months ( 5.5 years). In the 95th percentile of the BMI curve, the

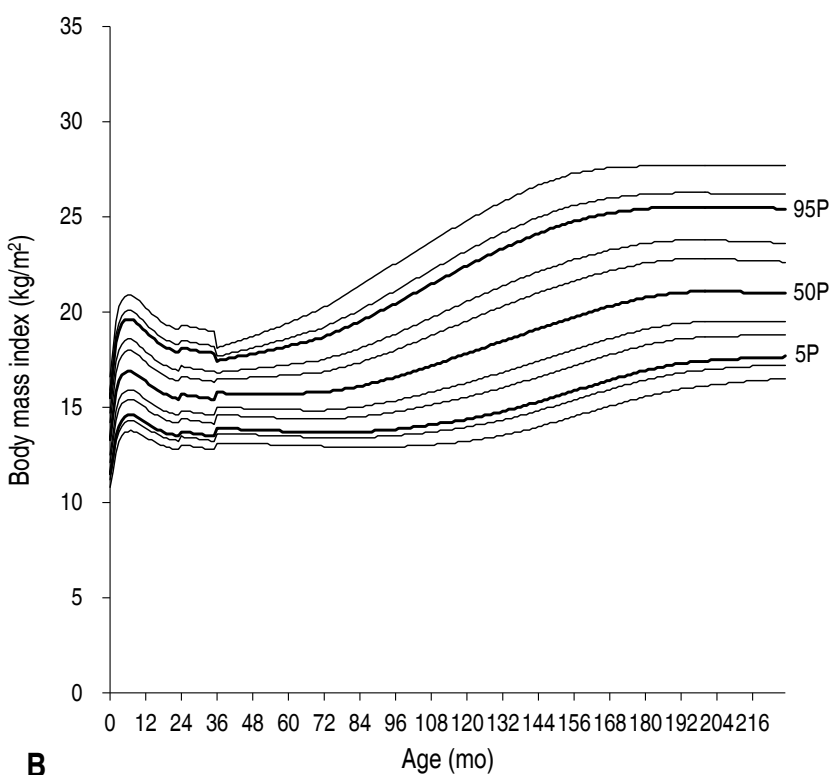

minimum BMI was $17.4 \mathrm{~kg} / \mathrm{m}^{2}$ and adiposity rebound occurred at age 37 months (3.1 years). The subsequent increase in BMI was more pronounced in the higher percentiles in both sexes, which was in accordance with the German Health Interview and Examination Survey for Children and Adolescents data. ${ }^{42)}$

\section{Trends of adiposity rebound in 21 st century children}

Globally, there has been a time shift in the BMI distribution and adiposity rebound timing. In Scotland, there has been a substantial shift of BMI distribution in the general population of a birth cohort born in 2004 compared with those born in 1990. ${ }^{43)}$ A longitudinal study in Japan showed that the mean age of having minimal BMI was 4.8 years in boys and 4.7 years in girls born between 1995 and 1996. ${ }^{5)}$ In the Czech Republic, compared with that in 1951, the time of adiposity rebound has gradually shifted to earlier ages in both boys and girls (Table 1). ${ }^{44)}$ Additionally, it has been suggested that the BMI velocity after adiposity rebound also changed over time. In the most recent cohort, boys and girls had greater maximum BMI velocities and adolescent BMI values than their counterparts in previous cohorts, although the BMI values at the age of adiposity rebound did not significantly differ. ${ }^{45}$

The timing of adiposity rebound has shifted not only among overweight and obese children, but also among children at the 10th percentile of BMI for age. Therefore, beyond the predictive role of later obesity, the secular trend of increased height, accelerated growth, and earlier maturation compared with that in the past may imply the timing of adiposity rebound. ${ }^{44)}$ Moreover, environmental factors such as low levels of physical activity, frequent television watching, and inappropriate feeding practices have been reported to 
Table 1. Trends in the timing of adiposity rebound in 21 st century children

\begin{tabular}{|c|c|c|c|c|c|c|}
\hline \multirow{2}{*}{$\begin{array}{l}\text { Country } \\
\text { Czech Republic }\end{array}$} & \multirow{2}{*}{$\begin{array}{l}\text { BMI } \\
\text { Year of the survey }\end{array}$} & \multicolumn{2}{|c|}{ Boys } & \multicolumn{2}{|c|}{ Girls } & \multirow{2}{*}{$\begin{array}{c}\text { Reference } \\
44)\end{array}$} \\
\hline & & 2001 & 1995 & 2001 & 1951 & \\
\hline & BMl 10P & $5.3 \mathrm{yr}$ & $6.4 \mathrm{yr}$ & $5.6 \mathrm{yr}$ & $6.5 \mathrm{yr}$ & \\
\hline & BMI 50P & $4.9 \mathrm{yr}$ & $6.2 \mathrm{yr}$ & $5.2 \mathrm{yr}$ & $6.4 \mathrm{yr}$ & \\
\hline & BMI 90P & $4.2 \mathrm{yr}$ & $6.0 \mathrm{yr}$ & $4.1 \mathrm{yr}$ & $5.8 \mathrm{yr}$ & \\
\hline \multirow[t]{4}{*}{ Poland } & Year of the survey & 2010 & 1983 & 2010 & 1983 & $57,58)$ \\
\hline & BMl 15P & $6.4 \mathrm{yr}$ & $7.7 \mathrm{yr}$ & $5.3 \mathrm{yr}$ & $7.4 \mathrm{yr}$ & \\
\hline & BMI 50P & $5.2 \mathrm{yr}$ & $7.5 \mathrm{yr}$ & $3.0 \mathrm{yr}$ & $7.4 \mathrm{yr}$ & \\
\hline & BMI 85P & $<3.0 \mathrm{yr}$ & $6.6 \mathrm{yr}$ & $<3.0 \mathrm{yr}$ & $7.3 \mathrm{yr}$ & \\
\hline \multirow[t]{4}{*}{ Germany } & Year of the survey & 2003-2006 & & 2003-2006 & & 42) \\
\hline & BMl 10P & $6.5 \mathrm{yr}$ & & $6.5 \mathrm{yr}$ & & \\
\hline & BMI 50P & $5.5 \mathrm{yr}$ & & $5.5 \mathrm{yr}$ & & \\
\hline & BMI 90P & $4.5 \mathrm{yr}$ & & $4.5 \mathrm{yr}$ & & \\
\hline \multirow[t]{5}{*}{ United States } & Year of the survey & 1999-2008 & & 1999-2008 & & 59) \\
\hline & BMI mean, White & $5.5 \mathrm{yr}$ & & $5.0 \mathrm{yr}$ & & \\
\hline & BMI mean, African American & $4.8 \mathrm{yr}$ & & $4.9 \mathrm{yr}$ & & \\
\hline & BMI mean, Hispanic & $4.8 \mathrm{yr}$ & & $5.1 \mathrm{yr}$ & & \\
\hline & BMI mean, Asian & $5.1 \mathrm{yr}$ & & $5.5 \mathrm{yr}$ & & \\
\hline
\end{tabular}

BMl, body mass index; P, percentile.

be responsible for early increase in BMI in some children. ${ }^{46)}$

\section{Novel insights into adiposity rebound in relation to body composition}

Because BMI reflects both FM and lean mass (LM), to confirm that the renewed increase of BMI is the true increase of adiposity, changes in body composition were studied. A small Dunedin study in girls that used dual-energy X-ray absorptiometry showed that early adiposity rebound was associated with increases in FM rather than LM, as expected. ${ }^{47)}$ However, several studies suggested that the direction of change in BMI and the LM index during the period of adiposity rebound was identical, ${ }^{48)}$ whereas an increase in the FM index lagged behind 2-3 years, particularly for boys. ${ }^{48,49)}$ On the basis of the evidence on changes in body composition, adiposity rebound coincided with a cessation of FM decline and an increase in LM. ${ }^{48,50)}$ Therefore, the timing of adiposity rebound was the indicator of individual development rather than increased body fat, ${ }^{48)}$ and a more accurate term for adiposity rebound would be "BMI rebound." ${ }^{\text {"2) }}$ In line with this, being tall at age 3 years, rather than having a high BMI at age 3 years, was shown to be associated with an earlier rebound. $^{51)}$

Williams and Goulding ${ }^{16)}$ found different rates of physical development between the early, average, and late rebound groups, with the late-rebound group reaching maturity later. Several other studies have also noted that a more rapid linear growth in infancy or tallness in early childhood is associated with early pubertal maturation or later obesity. ${ }^{52-54)}$ German et al. ${ }^{55)}$ studied the onset and tempo of puberty in relation to adiposity rebound, and showed that the early AR group had earlier pubarche and menarche in girls and a more rapid progression of puberty in boys than the later adiposity rebound group. Therefore, early adiposity rebound indicates faster growth, more advanced development, and earlier puberty. In this context, the finding that the shifting trends in adiposity rebound reflect the acceleration of growth in the 21st century is not surprising.

\section{Conclusions}

Although the timing of adiposity rebound has complex meanings, an important point is that BMI rebound has a impact on adverse health outcomes. Therefore, targeting modifiable factors in very early life to delay the timing of adiposity rebound is important. Nowadays, $63.3 \%$ of 0 - to 1-year-old children and $90.6 \%$ of 1 - to 5-year-old children spend time in some form of childcare center based on a childcare survey in 2013 by the Korea Institute of Child Care and Education. ${ }^{56)}$ Therefore, childcare settings should be involved in intervention efforts to prevent obesity. Additionally, health check-up programs for infants and children should be emphasized to screen for those at a high risk for early adiposity rebound.

\section{Conflicts of Interest}

There are no potential conflicts of interest relevant to this article. 


\section{References}

1. Rolland-Cachera MF, Deheeger M, Bellisle F, Sempé M, GuilloudBataille M, Patois E. Adiposity rebound in children: a simple indicator for predicting obesity. Am J Clin Nutr 1984;39:129-35.

2. Eriksson JG, Forsén T, Tuomilehto J, Osmond C, Barker DJ. Early adiposity rebound in childhood and risk of type 2 diabetes in adult life. Diabetologia 2003;46:190-4.

3. Bhargava SK, Sachdev HS, Fall CH, Osmond C, Lakshmy R, Barker DJ, et al. Relation of serial changes in childhood body-mass index to impaired glucose tolerance in young adulthood. N Engl J Med 2004; 350:865-75.

4. Eriksson JG. Epidemiology, genes and the environment: lessons learned from the Helsinki Birth Cohort Study. J Intern Med 2007;261: 418-25.

5. Koyama S, Ichikawa G, Kojima M, Shimura N, Sairenchi T, Arisaka 0. Adiposity rebound and the development of metabolic syndrome. Pediatrics 2014;133:e114-9.

6. Siervogel RM, Roche AF, Guo SM, Mukherjee D, Chumlea WC. Patterns of change in weight/stature2 from 2 to 18 years: findings from long-term serial data for children in the Fels longitudinal growth study. Int J Obes 1991;15:479-85.

7. Prokopec M, Bellisle F. Adiposity in Czech children followed from 1 month of age to adulthood: analysis of individual BMI patterns. Ann Hum Biol 1993;20:517-25.

8. Whitaker RC, Pepe MS, Wright JA, Seidel KD, Dietz WH. Early adiposity rebound and the risk of adult obesity. Pediatrics 1998;101:E5.

9. Williams S, Davie G, Lam F. Predicting BMI in young adults from childhood data using two approaches to modelling adiposity rebound. Int J Obes Relat Metab Disord 1999;23:348-54.

10. de Onis M, Blössner M, Borghi E. Global prevalence and trends of overweight and obesity among preschool children. Am J Clin Nutr 2010;92:1257-64.

11. Yoo BM, Kang MJ. Close connections between childhood obesity, parental obesity, and their salt intakes: Results of the 7th KNHANES, 2016. In: Poster session presentation at the International Congress on Obesity and Metabolic Syndrome; 2018 Sep; Seoul, Korea.

12. Kroke A, Hahn S, Buyken AE, Liese AD. A comparative evaluation of two different approaches to estimating age at adiposity rebound. Int $\mathrm{J}$ Obes (Lond) 2006;30:261-6.

13. Beyerlein A, Fahrmeir L, Mansmann U, Toschke AM. Alternative regression models to assess increase in childhood BMI. BMC Med Res Methodol 2008;8:59.

14. Maeyama K, Morioka I, Iwatani S, Fukushima S, Kurokawa D, Yamana $\mathrm{K}$, et al. Gestational age-dependency of height and body mass index trajectories during the first 3 years in Japanese small-for-gestational age children. Sci Rep 2016;6:38659.

15. Hughes AR, Sherriff A, Ness AR, Reilly JJ. Timing of adiposity rebound and adiposity in adolescence. Pediatrics 2014;134:e1354-61.

16. Williams SM, Goulding A. Patterns of growth associated with the timing of adiposity rebound. Obesity (Silver Spring) 2009;17:335-41.

17. Dietz WH. Critical periods in childhood for the development of obesity. Am J Clin Nutr 1994;59:955-9.

18. Rolland-Cachera MF, Deheeger M, Guilloud-Bataille M, Avons P, Patois E, Sempé M. Tracking the development of adiposity from one month of age to adulthood. Ann Hum Biol 1987;14:219-29.

19. Guo SS, Huang C, Maynard LM, Demerath E, Towne B, Chumlea WC, et al. Body mass index during childhood, adolescence and young adulthood in relation to adult overweight and adiposity: the Fels Longitudinal Study. Int J Obes Relat Metab Disord 2000;24:1628-35.

20. Freedman DS, Kettel Khan L, Serdula MK, Srinivasan SR, Berenson GS. BMI rebound, childhood height and obesity among adults: the
Bogalusa Heart Study. Int J Obes Relat Metab Disord 2001;25:543-9.

21. Dietz WH. "Adiposity rebound": reality or epiphenomenon? Lancet 2000;356:2027-8.

22. Hales CN, Barker DJ, Clark PM, Cox LJ, Fall C, Osmond C, et al. Fetal and infant growth and impaired glucose tolerance at age 64. BMJ 1991;303:1019-22.

23. Mo-Suwan L, McNeil E, Sangsupawanich P, Chittchang U, Choprapawon C. Adiposity rebound from three to six years of age was associated with a higher insulin resistance risk at eight-and-a-half years in a birth cohort study. Acta Paediatr 2017;106:128-34.

24. Eriksson JG. Early growth and coronary heart disease and type 2 diabetes: findings from the Helsinki Birth Cohort Study (HBCS). Am J Clin Nutr 2011;94(6 Suppl):1799S-1802S.

25. Doi L, Williams AJ, Frank J. How has child growth around adiposity rebound altered in Scotland since 1990 and what are the risk factors for weight gain using the Growing Up in Scotland birth cohort 1? BMC Public Health 2016;16:1081.

26. Giles LC, Whitrow MJ, Davies MJ, Davies CE, Rumbold AR, Moore VM. Growth trajectories in early childhood, their relationship with antenatal and postnatal factors, and development of obesity by age 9 years: results from an Australian birth cohort study. Int J Obes (Lond) 2015;39:1049-56.

27. Toschke AM, von Kries R, Beyerlein A, Rückinger S. Risk factors for childhood obesity: shift of the entire BMI distribution vs. shift of the upper tail only in a cross sectional study. BMC Public Health 2008;8: 115.

28. Ip EH, Marshall SA, Saldana S, Skelton JA, Suerken CK, Arcury TA, et al. Determinants of adiposity rebound timing in children. J Pediatr 2017;184:151-6.e2.

29. Andersen LG, Angquist L, Eriksson JG, Forsen T, Gamborg M, Osmond C, et al. Birth weight, childhood body mass index and risk of coronary heart disease in adults: combined historical cohort studies. PLoS One 2010;5:e14126.

30. Whincup PH, Kaye SJ, Owen CG, Huxley R, Cook DG, Anazawa S, et al. Birth weight and risk of type 2 diabetes: a systematic review. JAMA 2008;300:2886-97.

31. Dulloo AG, Jacquet J, Seydoux J, Montani JP. The thrifty 'catch-up fat' phenotype: its impact on insulin sensitivity during growth trajectories to obesity and metabolic syndrome. Int J Obes (Lond) 2006;30 Suppl 4:S23-35.

32. Oddy WH. Infant feeding and obesity risk in the child. Breastfeed Rev 2012;20:7-12.

33. Madsen AL, Schack-Nielsen L, Larnkjaer A, Mølgaard C, Michaelsen KF. Determinants of blood glucose and insulin in healthy 9-monthold term Danish infants; the SKOT cohort. Diabet Med 2010;27:13507.

34. Ravelli AC, van der Meulen JH, Osmond C, Barker DJ, Bleker OP. Infant feeding and adult glucose tolerance, lipid profile, blood pressure, and obesity. Arch Dis Child 2000;82:248-52.

35. Horta BL, Loret de Mola C, Victora CG. Long-term consequences of breastfeeding on cholesterol, obesity, systolic blood pressure and type 2 diabetes: a systematic review and meta-analysis. Acta Paediatr 2015;104:30-7.

36. Dietz WH Jr, Gortmaker SL. Do we fatten our children at the television set? Obesity and television viewing in children and adolescents. Pediatrics 1985;75:807-12.

37. Rolland-Cachera MF, Deheeger M, Akrout M, Bellisle F. Influence of macronutrients on adiposity development: a follow up study of nutrition and growth from 10 months to 8 years of age. Int J Obes Relat Metab Disord 1995;19:573-8.

38. Scaglioni S, Agostoni C, Notaris RD, Radaelli G, Radice N, Valenti M, et al. Early macronutrient intake and overweight at five years of age. 
Int J Obes Relat Metab Disord 2000;24:777-81.

39. Karaolis-Danckert N, Buyken AE, Kulig M, Kroke A, Forster J, Kamin $\mathrm{W}$, et al. How pre- and postnatal risk factors modify the effect of rapid weight gain in infancy and early childhood on subsequent fat mass development: results from the Multicenter Allergy Study 90. Am J Clin Nutr 2008;87:1356-64.

40. Kim JH, Yun S, Hwang SS, Shim JO, Chae HW, Lee YJ, et al. The 2017 Korean National Growth Charts for children and adolescents: development, improvement, and prospects. Korean J Pediatr 2018;61: 135-49.

41. Dorosty AR, Emmett PM, Cowin Sd, Reilly JJ. Factors associated with early adiposity rebound. ALSPAC Study Team. Pediatrics 2000;105: 1115-8.

42. Rosario AS, Kurth BM, Stolzenberg H, Ellert U, Neuhauser H. Body mass index percentiles for children and adolescents in Germany based on a nationally representative sample (KiGGS 2003-2006). Eur J Clin Nutr 2010;64:341-9.

43. Costa S, Adams J, Phillips V, Benjamin Neelon SE. The relationship between childcare and adiposity, body mass and obesity-related risk factors: protocol for a systematic review of longitudinal studies. Syst Rev 2016;5:141.

44. Vignerová J, Humeníkova L, Brabec M, Riedlová J, Bláha P. Longterm changes in body weight, BMI, and adiposity rebound among children and adolescents in the Czech Republic. Econ Hum Biol 2007; 5:409-25.

45. Johnson W, Soloway LE, Erickson D, Choh AC, Lee M, Chumlea WC, et al. A changing pattern of childhood BMI growth during the 20th century: 70 y of data from the Fels Longitudinal Study. Am J Clin Nutr 2012;95:1136-43.

46. Deheeger M, Rolland-Cachera MF, Fontvieille AM. Physical activity and body composition in 10 year old French children: linkages with nutritional intake? Int J Obes Relat Metab Disord 1997;21:372-9.

47. Taylor RW, Goulding A, Lewis-Barned NJ, Williams SM. Rate of fat gain is faster in girls undergoing early adiposity rebound. Obes Res 2004;12:1228-30.

48. Plachta-Danielzik S, Bosy-Westphal A, Kehden B, Gehrke MI,
Kromeyer-Hauschild K, Grillenberger M, et al. Adiposity rebound is misclassified by BMI rebound. Eur J Clin Nutr 2013;67:984-9.

49. Taylor RW, Williams SM, Carter PJ, Goulding A, Gerrard DF, Taylor BJ. Changes in fat mass and fat-free mass during the adiposity rebound: FLAME study. Int J Pediatr Obes 2011;6:e243-51.

50. Campbell MW, Williams J, Carlin JB, Wake M. Is the adiposity rebound a rebound in adiposity? Int J Pediatr Obes 2011;6:e207-15.

51. Williams S, Dickson N. Early growth, menarche, and adiposity rebound. Lancet 2002;359:580-1.

52. dos Santos Silva I, De Stavola BL, Mann V, Kuh D, Hardy R, Wadsworth ME. Prenatal factors, childhood growth trajectories and age at menarche. Int J Epidemiol 2002;31:405-12.

53. Safer DL, Agras WS, Bryson S, Hammer LD. Early body mass index and other anthropometric relationships between parents and children. Int J Obes Relat Metab Disord 2001;25:1532-6.

54. Luo ZC, Cheung YB, He Q, Albertsson-Wikland K, Karlberg J. Growth in early life and its relation to pubertal growth. Epidemiology 2003; 14:65-73.

55. German A, Shmoish M, Hochberg Z. Predicting pubertal development by infantile and childhood height, BMI, and adiposity rebound. Pediatr Res 2015;78:445-50.

56. Korea Institute of Child Care and Education. Childcare survey 2013 [Internet]. Seoul (Korea): Korea Institute of Child Care and Education; [cited 2018 Nov 3]. Available from: http://www.kicce.re.kr.

57. Kowal M, Kryst Ł, Woronkowicz A, Sobiecki J, Brudecki J, Żarów R. Long-term changes in BMI and adiposity rebound among girls from Kraków (Poland) over the last 30 years (from 1983 to 2010). Am J Hum Biol 2013;25:300-6.

58. Kowal M, Kryst Ł, Woronkowicz A, Brudecki J, Sobiecki J. Time trends in BMI, body fatness, and adiposity rebound among boys from Kraków (Poland) from 1983 to 2010. Am J Hum Biol 2015;27:64653.

59. Min J, Wen X, Xue H, Wang Y. Ethnic disparities in childhood BMI trajectories and obesity and potential causes among 29,250 US children: Findings from the Early Childhood Longitudinal Study-Birth and Kindergarten Cohorts. Int J Obes (Lond) 2018;42:1661-70. 